within six miles of the city were not enacted into law. Nor were proposals to provide for "automatic" annexation and the creation of metropolitan governments favorably received by the committee.

Although considerable wisdom and deliberation were reflected in the proposals made by the committee, an examination of them points inescapably to the conclusion that little imagination was used in their development. It seems doubtful that Oregon is going to blaze new trails in meeting the problems of its urban fringe areas. Perhaps it is wise to move slowly. A fact documented by the field studies is that people generally are not interested in radical modifications of the present pattern of local government. Results of the traditional arrangement are familiar, and people prefer to live with them rather than risk unknown consequences of new and different systems.

\title{
SOME ASPECTS OF \\ AMERICAN POLITICAL SCIENCE ORGANIZATION
}

\section{Cortez A. M. EWING*}

As one of the youngest of the social sciences, political science has made remarkable advances since the organization of the American Political Science Association in New Orleans in 1903. No one knows the exact numbers of political science teachers at that time, but in 1912 the APSA had only 267 instructors on its official membership rolls. And some of these, like Charles A. Beard, Albert Bushnell Hart, and Woodrow Wilson, were better known as historians than as political scientists. From this meagre beginning, the discipline has grown until there are now about 5,000 collegiate teachers, an equal number of upper echelon government officials, and another thousand who are professional researchers. The convenient roundness of figures springs from the lack of precise criteria for the definition of a political scientist.

The APSA grew steadily but not spectacularly in the first two decades of its existence. Thereafter, the growing politicization of America, together with increasing college enrollments, led to the employment of more instructors to teach more courses in citizenship and in professional political science. In 1958 APSA membership may reach 7,000; and that figure may well be doubled by 1970 unless a new wave of obscurantism sweeps across the American political reaches to depress further the public reputation of the egg-head.

When faced with the problem of numbers, the APSA might have initiated a federal type of organization, held both regional and national meetings, increased its publications, and encouraged the further development of political science as a learned and scientific discipline. Its failure

\footnotetext{
* University of Oklahoma.
} 
to federalize its structure invited the establishment of regional organizations, the first of which was the government section of the Southwestern Political and Social Science Association (1919). The Southern Political Science Association followed in the late thirties, the Western Political Science Association in the middle forties, and the Midwest Conference of Political Scientists in the middle fifties. For twenty years prior thereto the Midwestern group had met in annual discussion sessions but had not published a journal. And an Eastern association had folded after a promising start in the early thirties. In addition there are several fairly informal state and metropolitan organizations.

The regional associations appear at a critical time for the discipline. It lacks internal unity. It deals with the concept of power in organized society, a concept upon which there is wide disagreement among political scientists. The prevailing lack of unity may be a consequence of the origin of political science as a branch of moral philosophy and of the subsequent infusion of methods and materials from other intellectual disciplines - political economy, history, law, sociology, and social psychology - but the result has been the development of various schools in the discipline and an expansion more in the breadth than in depth.

The existence of these conflicting forces is an evidence of vitality. Every possible approach ought to be welcomed and encouraged. Much of the diversity springs from the natural conflict between the professional and the citizenship-training ideals. In fulfilling the demands of the latter purpose, the basic or gateway course in most American departments is American government. It is not necessarily a systematic course in the basic principles of political science. Subsequent training may feature courses in theory, international relations, public administration, or political parties, but these may be so loaded with descriptive administration or historical materials as to adumbrate the importance of principles.

With all the centrifugal forces operating in political science, there are equally strong unifying compulsions which can become the hard core of the discipline. Theory is certainly of this character, though there exists considerable disagreement as to whether theory should be political philosophy or a narrow-gauge theory of politics. Constitutional law, comparative government, methodology, and history of political science could well be added to theory to constitute the hardcore minimum for the four general areas - governmental institutions, public administration, popular government, and international relations. Though professional preparation for each of the areas must differ, recognition of the indispensability of knowledge and training common to all areas is a strong unifying force.

The regional organizations should contribute toward this unifying tendency in that they, like the national association, represent all schools of 
political science. If there were no regional organizations, the splinters would find it much easier to go their own way. Professional political scientists should find it possible to support both national and regional organizations, as well as any specialized group with which their interests are most closely identified. If this is done, each new approach may make its contribution to political science and the future shall witness the development of a discipline rich in knowledge and unified in structure.

\section{THE ESTABLISHMENT OF SOCIAL PRIORITIES}

\section{VICTOR C. FERKISS*}

Each era of our national history appears, in the focus provided by hindsight, to have been dominated by a single theme to which all its myriad problems were in some way related. It is my contention that in the next twenty years the general problem which will underlie all our specific problems will be the need for the establishment of a system of social priorities. Unless we can adopt and implement a schedule of priorities for social action, America in the years to come will not only be more ugly and less just, but will also be less secure, since we shall be unlikely to gain, and perhaps will not even merit, the support of the uncommitted peoples of the world.

In the recent past American political thinkers, including most practicing politicians as well as academics, have accepted as valid the theory that there is no such thing as the public interest and that in a democracy the action of government can only be the resultant of the clashing pressures brought to bear by divergent special interests. This belief may have been adequate as a basis for action in an era when our problem was primarily one of reviving an economy which was moribund because of the depressed status of important segments of our population. By seeking to improve their position relative to other social groups, such special interests as labor and the farmers served a broader social purpose. Because World War II came at a time when there was still underutilization of our human and physical resources, the United States was able to achieve its national aims without requiring substantial sacrifices on the part of any of its major social groups.

In the era of the Cold War, however, we are increasingly faced with a situation in which there may not be enough social resources to go around, and we cannot continue to act as though the public interest or, to use its ancient name, the common good, has no objective correlate. Maintenance of an adequate level of national defense and foreign aid, urban planning, proper development of our natural and cultural resources - all these problems are insoluble unless we can create the intellectual, institutional

\footnotetext{
* St. Mary's College, California.
} 